\title{
Chemical Stabilization of Soft Clay Soil Using Electrokinetic Method
}

\author{
Lakshmi Priya. ${ }^{1}$, Sivaranjani. ${ }^{2}$ \\ 1,2 Pg Students Division Of Structural Engg Mnm Jain Engg College Thoraipakkam,Chennai.
}

\begin{abstract}
Electrokinetic principle are being used in many geotechnical engineering application such as dewatering, decontamination, soil enhancement etc. Electrokinetic cell has been fabricated in which provisions are given to collect the water at cathode and varying the spacing of electrodes. In this paper an attempt is made to stabilize the soil for varying voltage, spacing of electrodes and initial moisture content. On application of current, the volume of water collected were determined at regular intervals till the steady state volume of water is reached. Results indicated that rate of dewatering process is largely influenced by the voltage, spacing between the electrodes and initial moisture content.
\end{abstract}

Keywords : ammeter, electrodes, lime, stabilization and voltmeter

\section{Introduction}

Problematic soils are characterized by their low bearing capacity, high compressibility and high volume change and as such they are not suitable for geotechnical engineering applications. Soft clays pose a great challenge to use the same as a good construction material. Attempts have been constantly made to enhance the behavior of such problematic soils through ground improvement techniques such as dewatering, grouting and various other methods.

Shang (1996) made an attempt to enhance the dewatering process in clay slurries using electrokinetic principle. Tests were conducted on two different clays by applying different voltages. It was concluded that within 30 hours, the water content of the tested clay slurries reduced to their liquid limit water content. There was considerable increase in the untrained shear strength and decrease in moisture content. It was also commented that electrokinetic method is simple and inexpensive.

Buckland et al (2000) conducted an experimental study on the electrokinetic sedimentation of contaminated well and river sediment. The application of electrokinetics was found to significantly increase the free settling velocity of sediment. It was concluded that a continuous DC current generated a better performance than intermittent current and electrokinetic sedimentation is more effective than chemical coagulation.

Electrokinetic phenomena is the process of removing the fluid from the soil by electrical conductivity. It is effectively used to increase the rate of consolidation with and without prefabricated vertical drains. The electrokinetic processes reportedly cause a decrease in the water content and increase the plastic limit and shear strength of the clay. In order to stabilize the clays, electro-kinetic process are being widely used because of their advantages such as: low cost, non-intrusive character, applicability to a wide range of contaminants and insensitivity to pore size soil that makes it suitable for fine-grained soils.

\subsection{Materials}

\section{Headings}

Soil samples were collected from SIPCOT, Chennai for the present study. The liquid and plastic limit of the soil is $54.086 \%$ and $28.61 \%$ respectively. The soil is classified as ' $\mathrm{CH}$ ' type. The lime was purchased for about $10 \mathrm{~kg}$ in readymade. The physical properties of soil is shown in table 1.

\subsection{Methods}

In order to study the electrokinetic phenomena in soils, an electrokinetic cell was designed and fabricated which has the components like rectangular box open at top, electrodes, voltmeter, ammeter, AC to DC transformer and multimeter. Figure 1 shows the schematic diagram of the fabricated cell. The dimensions of the box are $500 \times 150 \times 150 \mathrm{~mm}$. The soil sample of varying initial moisture content will be placed in the tube up to a height of $10 \mathrm{~cm}$ by hand remolding. At the cathode end, provision is given at the bottom of box to collect the drained water during the process of passage of current across the soil sample. The voltmeter is provided to measure the voltage applied. The voltage can be varied as $40 \mathrm{~V}$ and $80 \mathrm{~V}$. The ammeter is used to measure the amount of current passing through the soil sample. The ammeter is capable of measuring current from $1 \mathrm{~A}$ to 10 A. The cathodic electrode is made up of copper with perforations to facilitate removal of water and the anodic electrode is made up of zinc. The transformer converts the incoming AC current to DC current. The transformer, voltmeter and ammeter are fitted together in a small box so that the apparatus is compact. 
The following procedure is adopted in electrokinetic method for dewatering:

- The rectangular box is filled with soil sample.

- The soil sample and lime stabilization of varying initial moisture content will be placed in the box.

- The electrodes are fitted at either end of the box with the help of slits provided and depending upon the spacing between the electrodes.

- At the cathode, provision is given to collect water during the process of passage of voltage across the soil sample.

- The box is electrically connected to the transformer set-up.

- On applying the required voltage across the electrodes for a specific time, the water is simultaneously collected at the cathode.

- The volume of water collected is noted at different time intervals.

- Soil samples are taken at different points along the length of the box to find the water contents at different time intervals.

- Results would be compared for different voltages and IMC.

- The duration of the test depends upon the time taken for the water collected at cathode to achieve a steady rate.

\section{FIgURES AND TABLES}

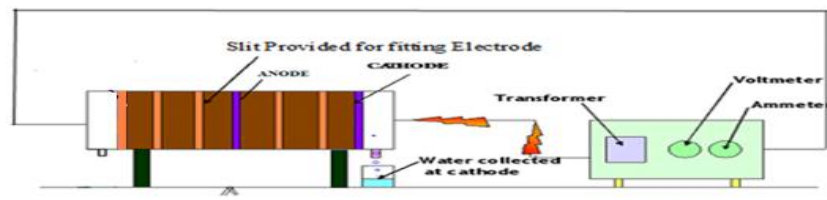

Fig1: schematic diagram of electrokinetic cell

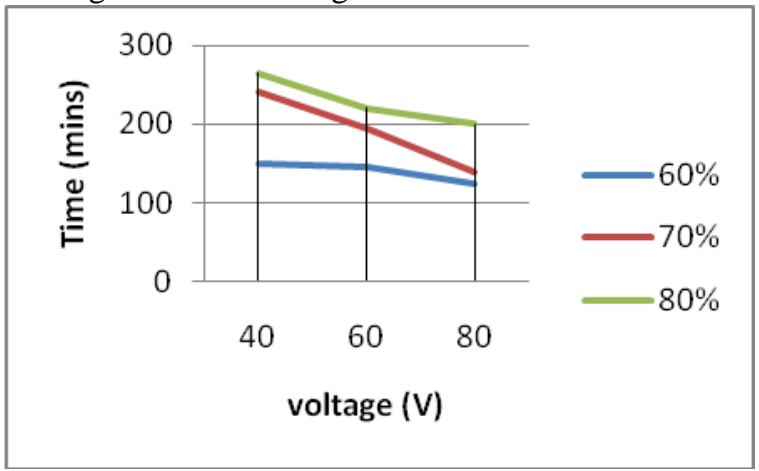

Fig 2 comparison of variation of time required to attain steady state of volume of water collected at different voltage and imc $60 \%, 70 \%$ and $80 \%$

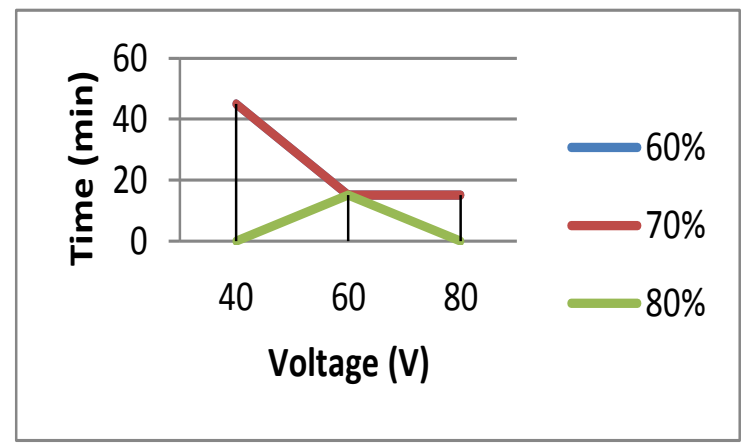

Fig 3. comparison of variation of time required to attain steady state of volume of water collected at different voltage and imc $60 \%, 70 \%$ and $80 \%$ in lime stabilization. 


\section{TABLE 1: Physical Properties Of Soil}

\begin{tabular}{|l|l|}
\hline Properties & Soil \\
\hline Specific gravity & 2.71 \\
\hline Liquid limit, \% & 54.086 \\
\hline Plastic limit, \% & 28.61 \\
\hline Plasticity index, \% & 25.476 \\
\hline Shrinkage limit, \% & 9.3 \\
\hline Free swell index, \% & 78 \\
\hline Max. dry density, $\mathrm{kg} / \mathrm{m}^{3}$ & 1.65 \\
\hline Optimum moisture content, \% & 23.36 \\
\hline Swell classification & Very high \\
\hline Soil classification as per IS & $\mathrm{CH}$ \\
\hline
\end{tabular}

TABLE 2 Time Lapse For Achieving Steady Volume Of Water For 60\%,70\% and 80\% IMC Of Soil For Varying Voltage In Dewatering

\begin{tabular}{|l|l|l|l|l|}
\hline $\begin{array}{l}\text { Spacing Between } \\
\text { Electrodes }(\mathrm{cm})\end{array}$ & $\begin{array}{l}\text { Voltage } \\
\mathrm{V})\end{array}$ & $\begin{array}{l}\text { Time Taken To Attain Steady } \\
\text { Volume of water at cathode ( min }), \\
\text { IMC }\end{array}$ \\
\cline { 3 - 6 } & & $60 \%$ & $70 \%$ & $80 \%$ \\
\hline \multirow{3}{*}{10} & 40 & 150 & 240 & 265 \\
\cline { 2 - 5 } & 60 & 145 & 195 & 220 \\
\cline { 2 - 5 } & 80 & 125 & 140 & 200 \\
\hline
\end{tabular}

TABLE 3. Time Lapse For Achieving Steady Volume Of Water For 60\%,70\% and 80\% IMC Of Soil For Varying Voltage In Lime Stabilization.

\begin{tabular}{|c|l|l|l|l|}
\hline \multirow{2}{*}{$\begin{array}{c}\text { Spacing Between } \\
\text { Electrodes }(\mathrm{cm})\end{array}$} & $\begin{array}{l}\text { Voltage ( } \\
\text { V ) }\end{array}$ & \multicolumn{4}{|c|}{$\begin{array}{l}\text { Time Taken To Attain Steady Volume } \\
\text { of water at cathode ( min ), IMC }\end{array}$} \\
\cline { 3 - 5 } & & $60 \%$ & $70 \%$ & $80 \%$ \\
\hline \multirow{3}{*}{10} & 40 & 45 & 45 & $\begin{array}{l}\text { Water is } \\
\text { evaporated }\end{array}$ \\
\cline { 2 - 5 } & 60 & 15 & 15 & 15 \\
\cline { 2 - 5 } & 80 & 15 & 15 & $\begin{array}{l}\text { Water is } \\
\text { evaporated }\end{array}$ \\
\hline
\end{tabular}

\section{Conclusion}

Prepared soft clay bed (with varying consistency) has been subjected to varying spacing of electrodes, voltage for different time intervals in the fabricated electrokinetic cell. During the application of current, the volume of water collected at the cathode points and changes in the water content were collected at regular intervals are analyzed here. The results before and after passage of current are analyzed.

\subsection{Effect of voltage}

\subsubsection{Dewatering by electrokinetic phenomena}

The applied voltage is one of the important parameters that control the effectiveness of electro-osmosis. Even though the operating voltage of in-situ stabilization of soft clay using electrokinetic phenomena is varying between $10 \mathrm{~V}$ to $80 \mathrm{~V}$, in the present case three voltages via, $40 \mathrm{~V}, 60 \mathrm{~V}$ and $80 \mathrm{~V}$ have been selected to study the effect of same on soils.

Table 2 show the volume of water collected at cathode (spaced $10 \mathrm{~cm}$ away from anode) with time for $40 \mathrm{~V}$, $60 \mathrm{~V}$ and $80 \mathrm{~V} \mathrm{DC}$ and IMC of $60 \%, 70 \%$ and $80 \%$ respectively. It can be seen that the cumulative constant value corresponding to $265 \mathrm{~min}$ irrespective of IMC. However at specified time intervals, the volume of water collected at cathode point increases, where in effect of voltage do not seem to alter significantly the dewatering processes.

\subsubsection{Lime stabilization by electrokinetic phenomena}

One of the parameters influencing in the effectiveness of electro osmotic process is the voltage. In the present investigation, the soil has been subjected to voltage varying from $40 \mathrm{~V}, 60 \mathrm{~V}$ and $80 \mathrm{~V}$ DC and its effect on the removal of variation in moisture contents for spacing between electrodes are studied Table 3 show the volume of water collected at cathode with time for $40 \mathrm{~V}, 60 \mathrm{~V}$ and $80 \mathrm{~V}$ DC and IMC of $60 \%$, $70 \%$ and $80 \%$ respectively. It can be seen that the cumulative volume of water collected at cathode increases steadily and reaches to a constant value corresponding to $60 \mathrm{~min}$ irrespective of IMC. However at specified time intervals, the volume of water collected at cathode point increases, where in effect of voltage do not seem to alter significantly the dewatering processes. 


\section{Acknowledgements}

We express our sincere thanks to our guide Mrs. C.A.. POORNIMA M.E., for her encouragement for the progress, we also thank our assistant professor Mr. DHANASEKARAN and Mr. DEEPAK RAJ for their valuable support.

\section{Journal Papers:}

\section{References}

[1] Krishna Reddy and Chintham Reddy (2003). :Sequentially Enhanced Electrokinetic Remediation of Heavy Metals in Low Buffering Clayey Soils", ASCE, Vol, 12 (9), pp. 445-450.

\section{Books:}

[2] Purshothama Raj, P., 1999, Ground improvement Techniques, Lakshmi publications.

\section{Theses:}

[3] Nandda Gopalan and V.K. Stalin (2008) “A Study on Decontamination and Stabilization of Problematic clays through Eectrokinetic Phenomena". A Post Graduate thesis submitted to Department of Civil Engineering, Anna University, Chennai-25.2008 